\title{
Environmental influences on spatio-temporal oceanic distribution of ichthyoplankton around the Kerguelen Islands (Southern Ocean)
}

\author{
P. Koubbi ${ }^{1}$, F. Ibanez ${ }^{2}$, G. Duhamel ${ }^{1}$ \\ ${ }^{1}$ Muséum National d'Histoire Naturelle, Laboratoire d'Ichtyologie générale et appliquée, 43 rue Cuvier, \\ F-75231 Paris Cedex 05, France \\ ${ }^{2}$ Centre d'Etude et de Recherches Océanographiques de Villefranche-sur-Mer, Station Zoologique, \\ F-06230 Villefranche-sur-Mer, France
}

\begin{abstract}
Ichthyoplankton of the oceanic zone surrounding the Kerquelen Islands (northern part of the Indian sector of the Southern Ocean) was studied. The results concerning both abundance and spatial distribution of fish eggs and larvae are discussed. Samples were collected during joint FrenchSoviet oceanographic cruises in summer, autumn and winter 1987 and summer 1988. The presence of the Antarctic Polar Front allowed us to show latitudinal distribution of the ichthyoplankton. Topography played an important role in separating mesopelagic and demersal species.
\end{abstract}

\section{INTRODUCTION}

Topographic factors influence the distribution of antarctic fishes. Indeed, the Southern Ocean ichthyofauna is made up of species belonging to 2 major taxonomic groups (Fischer \& Hureau 1987), distinguished from each other according to their bathymetric affinities. One group, the Notothenioidei, is composed of demersal species living on shelves and seamounts. The other, the Myctophidae, contains both mesopelagic and bathypelagic species. The spatial distribution of these species is influenced by the characteristics of water masses (Hulley 1981, Bekker 1985).

The oceanic zone surrounding the Kerguelen Islands $\left(49^{\circ} 21^{\prime} \mathrm{S}, 70^{\circ} 12^{\prime} \mathrm{E}\right)$ is strongly influenced by the Antarctic Circumpolar Current. One of the main hydrological characteristics of that zone is that it is limited to the north by a transition zone formed by the joining of 2 fronts, namely the Subantarctic Front and the Subtropical Convergence (Gambéroni et al. 1982; Charriaud \& Gambéroni 1987). One must also note the presence of another front, the Antarctic Polar Front, situated by the Kerguelen Island shelf (located in the northern part of the Kerguelen Plateau). This latter front is characterized by the antarctic temperature minimum (Deacon 1934). These hydrological fronts play an essential role in determining the spatial heterogeneity and dynamics of plankton (Ledenev 1966). The presence of the Antarctic Polar Front will be taken into account in this study.

The topography of the region will also be considered. The study area extends as far as $300 \mathrm{~km}$ around the Kerguelen Islands (see Fig. 1) and covers: (1) the wide island shelf $\left(100495 \mathrm{~km}^{2}\right)$ that mainly extends northwestwardly at depths between 0 and $500 \mathrm{~m}$, (2) the 'Skiff seamount', which is separated from the Kerguelen shelf by an area with depths $>1000 \mathrm{~m}$, (3) the 'Kerguelen-Heard seamounts', which are separated from the island shelf by an area with depths of $700 \mathrm{~m}$, and (4) the deep oceanic zone surrounding the area.

In this article, we examine the influence of the above abiotic factors on spatio-temporal distribution of ichthyoplankton in the vicinity of the Kerguelen Islands.

\section{MATERIALS AND METHODS}

Sampling. Four oceanographic cruises were carried out from the $82 \mathrm{~m}$ Soviet scientific trawler 'Skif' (Table 1). Samples and measurements were taken along 8 radial transects (made up of 52 stations) which formed a star shape centered on the archipelago (Fig. 1) The nearshore zone, a 12 mile $(22 \mathrm{~km})$ belt around the archipelago, was not sampled. Three addi- 
Table 1. Periods of the 4 joint French-Soviet oceanographic cruises in 1987 and 1988 in the oceanic zone surrounding the Kerguelen Islands, Southern Ocean

\begin{tabular}{|c|c|c|c|}
\hline \multicolumn{2}{|c|}{ Season } & $\frac{\text { Beginning }}{3 \mathrm{Feb}}$ & $\begin{array}{c}\text { End } \\
15 \mathrm{Feb}\end{array}$ \\
\hline 1987 & $\begin{array}{l}\text { Summer } \\
\text { Autumn } \\
\text { Winter }\end{array}$ & $\begin{array}{l}3 \text { Feb } \\
31 \mathrm{Mar} \\
24 \mathrm{Jul}\end{array}$ & $\begin{array}{r}15 \text { Feb } \\
12 \text { Apr } \\
6 \text { Aug }\end{array}$ \\
\hline 1988 & Summer & 7 Feb & $20 \mathrm{Feb}$ \\
\hline
\end{tabular}

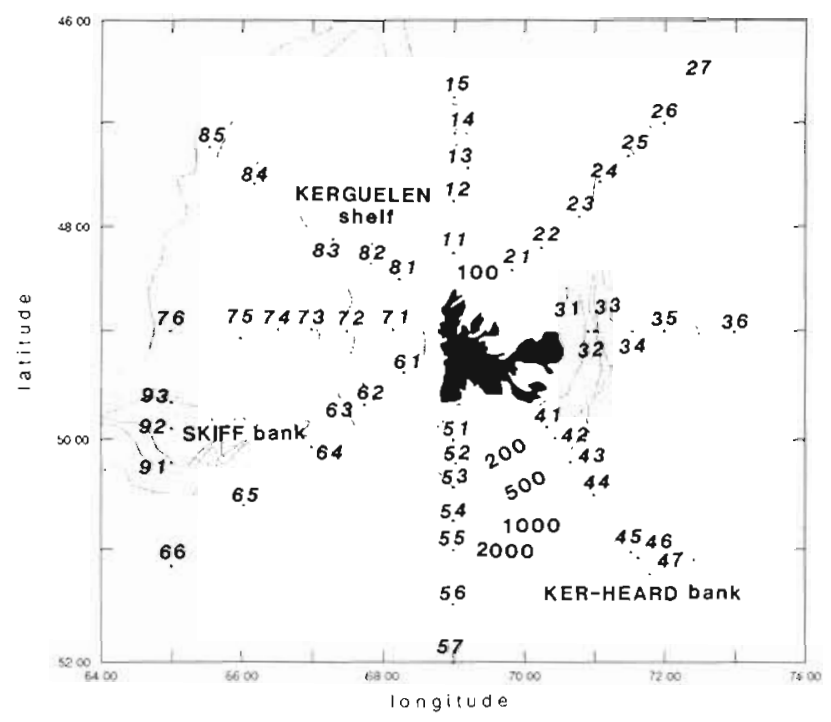

Fig. 1. Geographic location of hydrologic, meteorologic and planktonic stations (designated by numbers) off the Kerguelen Islands, where samples and measurements were taken during 4 cruises in 1987 and 1988

tional stations were located on the Skiff seamount. Meteorological and hydrological measurements, as well as plankton samples, were taken at each station.

Meteorological observations: Standard meteorological measurements were taken, including observations of sea state and cloud cover. Only the wind factors, direction and speed, are taken into account in this study, because of their possible influence on ichthyoplankton transport.

Hydrological measurements: Nansen type reversing bottles (1.8l) were lowered down to the international standard depths (between 0 and $1000 \mathrm{~m}$ ). Temperatures were taken with reversing thermometers; salinity was measured with an inductive salinometer.

Ichthyoplankton: A Bongo net was used for sampling as recommended by Smith \& Richardson (1977) and Hureau (1982). This sampling device consisted of 2 frames ( $63 \mathrm{~cm}$ diameter) mounted in tandem. Each frame was equipped with a $0.5 \mathrm{~mm}$ mesh cylindrical conical net, $3.6 \mathrm{~m}$ in length. This mesh is recommended for sampling in the Southern Ocean in order to avoid problems of phytoplankton clogging (Hureau
1982). Flowmeters fixed on the centre of each frame were used to measure the volume of water filtered. Oblique tows were made at a speed of 2 to 3 knots (from the surface down to the fished depth). For shallow tows (depth $<200 \mathrm{~m}$ ) the Bongo net was lowered close to the bottom. Otherwise, it was lowered to $200 \mathrm{~m}$ depth. Net depth was determined during tows by using the wire angle for the first 3 cruises and a bathykimograph for the last cruise. This towing procedure seems to be appropriate for the area, as confirmed by Kellermann (1986), who found that $98.6 \%$ of ichthyoplankton (from the Antarctic Peninsula) occurred in the upper $200 \mathrm{~m}$

Samples were fixed in seawater formalin $(5 \%)$ buffered with sodium borate and kept in darkness at a temperature of between 5 and $10^{\circ} \mathrm{C}$. Afterwards, in the laboratory, zooplankton samples were sorted and fish larvae removed under a stereomicroscope.

Identification of notothenioid larvae was carried out using descriptions provided by Kellermann (1989) and Koubbi et al. (1990). Myctophid larvae were identified according to Moser \& Ahlstrom (1970), Efremenko (1979) and North \& White (1982). Pelagic eggs were identified by comparing their mean diameters with those of mature oocytes (Duhamel 1987a, b). We also took into account the season of presence of those eggs in plankton and the spawning periods of the main Kerguelen fishes (Duhamel 1987a, b). Counts of all eggs and larvae were converted into no. of ind. per $10000 \mathrm{~m}^{3}$.

Numerical methods: The influence of abiotic factors on ichthyoplankton spatial distribution cannot be determined by means of a correlation analysis between them. In addition to limits imposed by linearity, correlations can only detect a possible link between increasing and monotonous gradients.

We chose to apply the Multiple Correspondence Analysis technique (Volle 1985). Each biological or environmental variable, whether qualitative or quantitative, was divided into a limited number of classes and analyzed for each cruise. Abiotic and biological variable classes were presented in columns, and observations in rows. Contingency boxes corresponded to an observation's characteristic: 0 for all the missing descriptor classes or 1 for all the present classes. Correspondence Analysis performed on that contingency table allowed us to represent the modalities of each descriptor and observation simultaneously in the same analytical framework. We chose a representation of biological and environmental associations in the geographical space from the Correspondence Analysis results. All the classes of descriptor and observation coordinates placed on the first 5 axes of inertia (more than $40 \%$ of the total inertia) were used to calculate their inter-distance and to carry out a classification based on the Lance and 
Williams algorithm (Lance \& Williams 1967). This consists of a flexible clustering $(\beta=-0.3)$. Visualisation of the dendrogram shows the presence of different groups that contain both stations and classes of descriptors. Then we defined geographical zones from the stations which belonged to the same group. These zones are associated with some classes of descnptors that appear mainly in these locations

This method is linked to 3 arbitrary operations, namely, the choice of descriptor classes, the number of inertia axes to be kept, and the threshold of distance from the dendrograms.

\section{RESULTS AND DISCUSSION}

\section{Meteorology}

Meteorological conditions encountered during the study consisted of permanent, regular, high winds. Average speeds were ca $4 \mathrm{~m} \mathrm{~s}^{-1}$; it should be stressed that this is an underestimate, since no stations were visited, and therefore no measurements taken, during storms. Azibane et al. (1977) reported an annual average wind speed of $9.7 \mathrm{~m} \mathrm{~s}^{-1}$. The winds all came from the western quadrant.

\section{Hydrology}

Temperature/salinity diagrams for summer and autumn 1987 and summer 1988 (Figs. 2 to 4 ) show the presence of the Antarctic temperature minimum in subsurface water (Koubbi unpubl. data), indicating the presence of the Antarctic Polar Front. Thus there are 2 regions within the study area - one in the northwest, the other in the southeast - separated by the 5 to $5.5^{\circ} \mathrm{C}$ isotherm and the $33.75 \%$ isohaline. In the northwestern part, waters are warmer, less salune and relatively homogeneous. In the southeast, there are thermal and salinity gradients. In summer 1988 , the 4.5 to $6.5^{\circ} \mathrm{C}$ isotherms were further northward in companson with summer 1987.

Temperatures in winter 1987 (Fig. 5a) were normally $2{ }^{\circ} \mathrm{C}$ less than those of summer. Salinities were almost identical to those of other seasons. The Antarctic Polar Front separated 2 regions, defined by the $3^{\circ} \mathrm{C}$ isotherm and the $33.80 \%$ isohaline. Lower-salınity water was present in the northeastern part of the archipelago; this water mass extended to the northeast shelf/slope break.

\section{Ichthyoplankton}

There were 15 ichthyoplanktonic taxa found. Larvae from mesopelagic species dominated the catches (ca
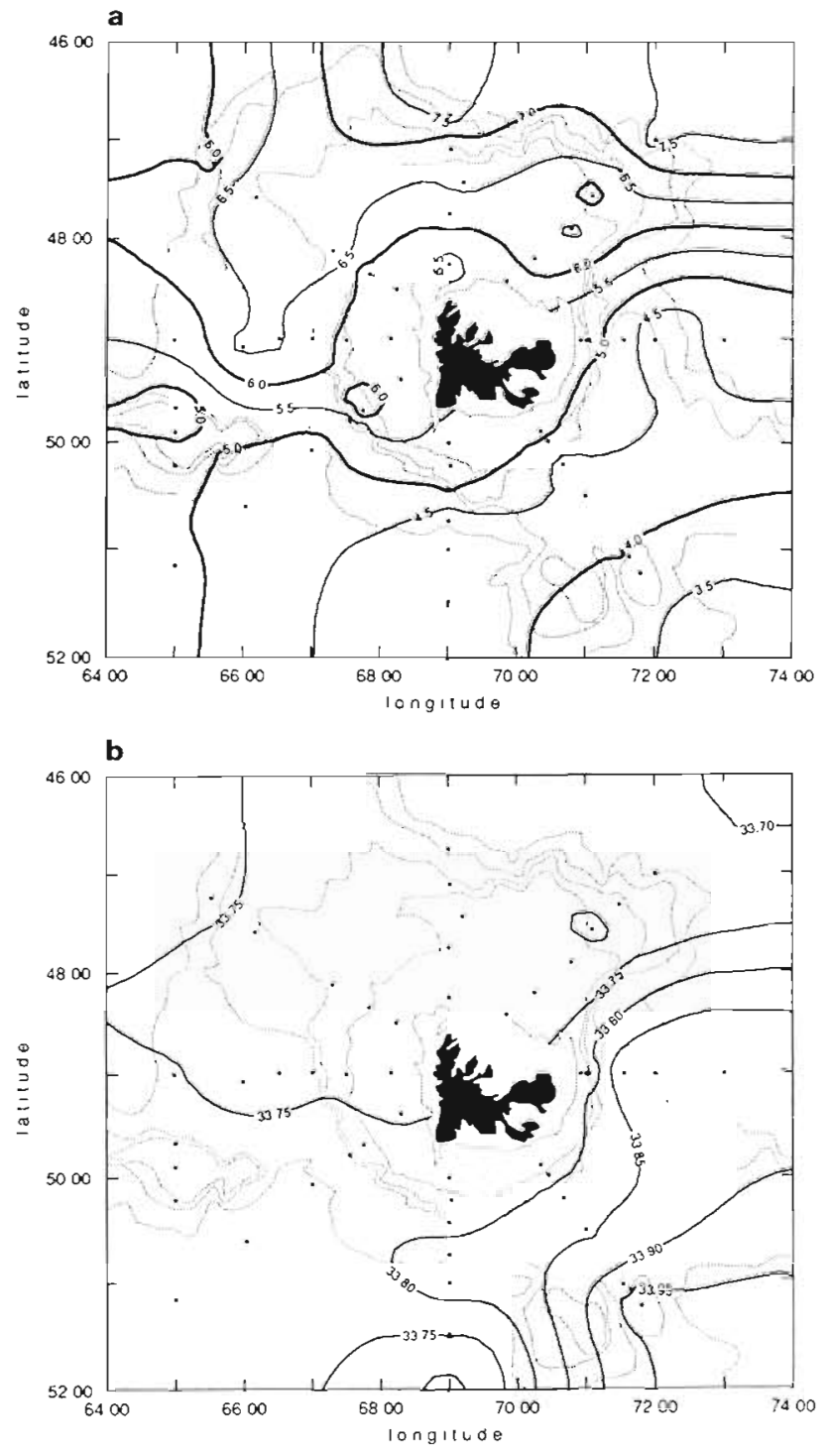

Fig. 2 Hydrologic conditions, summer 1987 (a) Surface temperatures $\left({ }^{\circ} \mathrm{C}\right)$, (b) surface salınities $(\%)$

$95 \%$ ), followed by nototheniond larvae. Seasonal diversities are low ( 8 taxa approximately), because of the small number of species found in the area (55) and because demersal species spawn in different seasons and geographic sectors (Duhamel 1987a, b). Lack of sampling in the nearshore zone and in spring may also have influenced the number of taxa collected.

The following 4 groups can be identified based on seasonal presence or absence: (1) Species whose larvae are found in summer and autumn (Lepidonotothen squamifrons and larvae of the genus Gymnoscopelus). These species spawn at the end of spring, as verified for L. squamifrons by Duhamel \& Ozouf-Costaz (1985) and Duhamel (1987a, b) Zanchlorhynchus spinifer juveniles are found in the plankton during summer and autumn and can be included in this group. (2) Species 

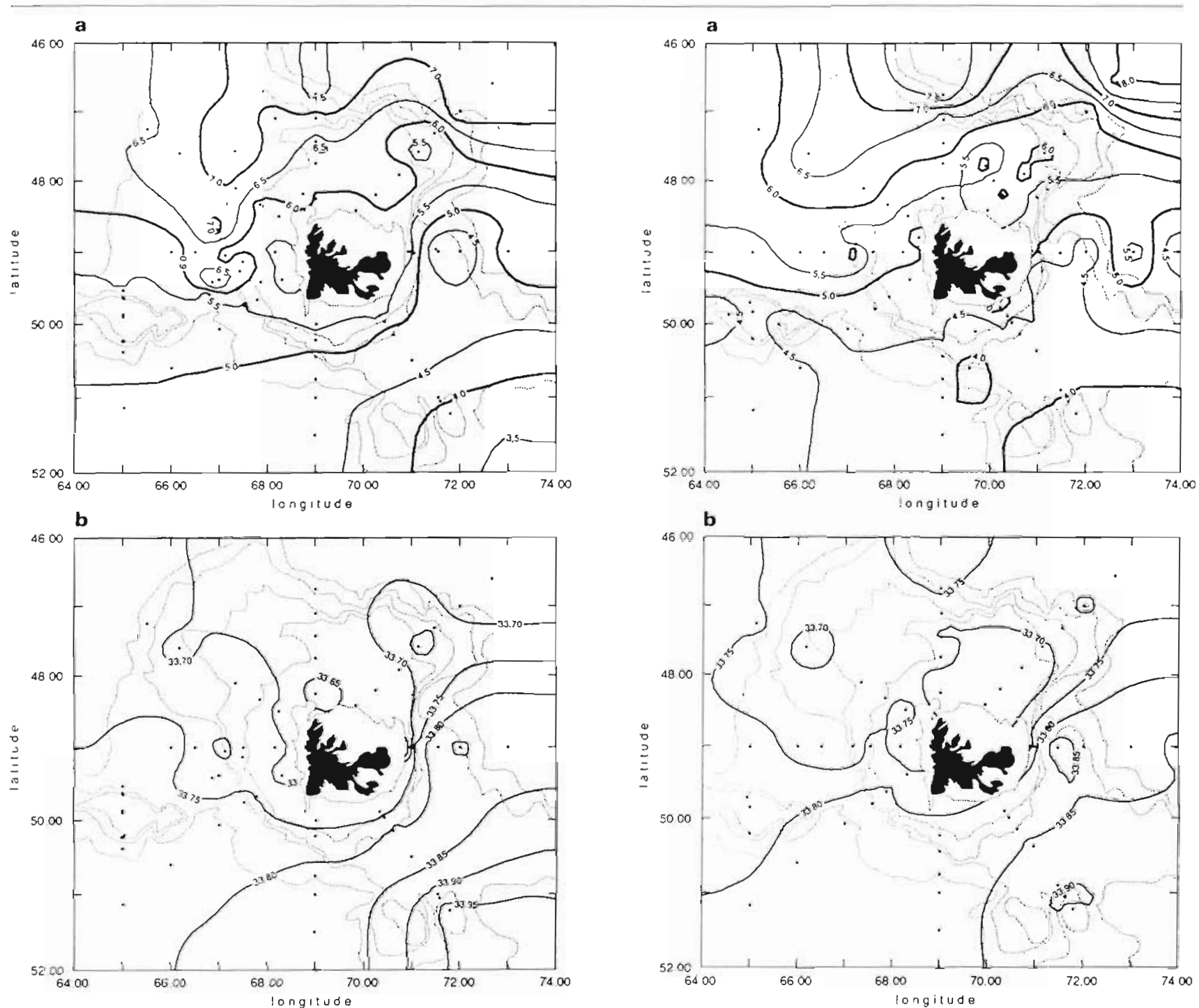

Fig 3 Hydrologic conditions, autumn 1987 (a) Surface temperatures $\left({ }^{\circ} \mathrm{C}\right)$, (b) surface salınities $(\%$ o)

Flg 4 Hydrologic conditions, summer 1988. (a) Surface temperatures $\left({ }^{\circ} \mathrm{C}\right)$, (b) surface salinities $(\%)$

Table 2 Seasonal medıan of ichthyoplanktonic abundances (no of individuals per $10000 \mathrm{~m}^{3}$ ), (-) Indicates no specimens found

\begin{tabular}{|c|c|c|c|c|}
\hline Species & Summer 1987 & Autumn 1987 & Winter 1987 & Summer 1988 \\
\hline \multicolumn{5}{|l|}{ Myctophidae } \\
\hline Protomyctophum sp & 12 & 36 & 18 & 16 \\
\hline Krefftichthys anderssoni & 37 & 108 & 975 & 44 \\
\hline Gymnoscopelus brauen & 80 & 47 & 9 & 51 \\
\hline Gymnoscopelus nicholsi & 29 & 34 & - & 22 \\
\hline Myctophidae (all species) & 156 & 148 & 975 & 169 \\
\hline \multicolumn{5}{|l|}{ Nototheniidae } \\
\hline Lepidonotothen squamifrons & 24 & 37 & - & 21 \\
\hline Lepidonotothen mizops & - & - & 26 & 39 \\
\hline \multicolumn{5}{|l|}{ Other species } \\
\hline Zanchlorhynchus spinifer & 36 & 16 & - & 12 \\
\hline \multicolumn{5}{|l|}{ Notothenioid eggs } \\
\hline Notothena rossiz & - & - & 77 & - \\
\hline Champsocephalus gunnar & - & - & 43 & - \\
\hline
\end{tabular}



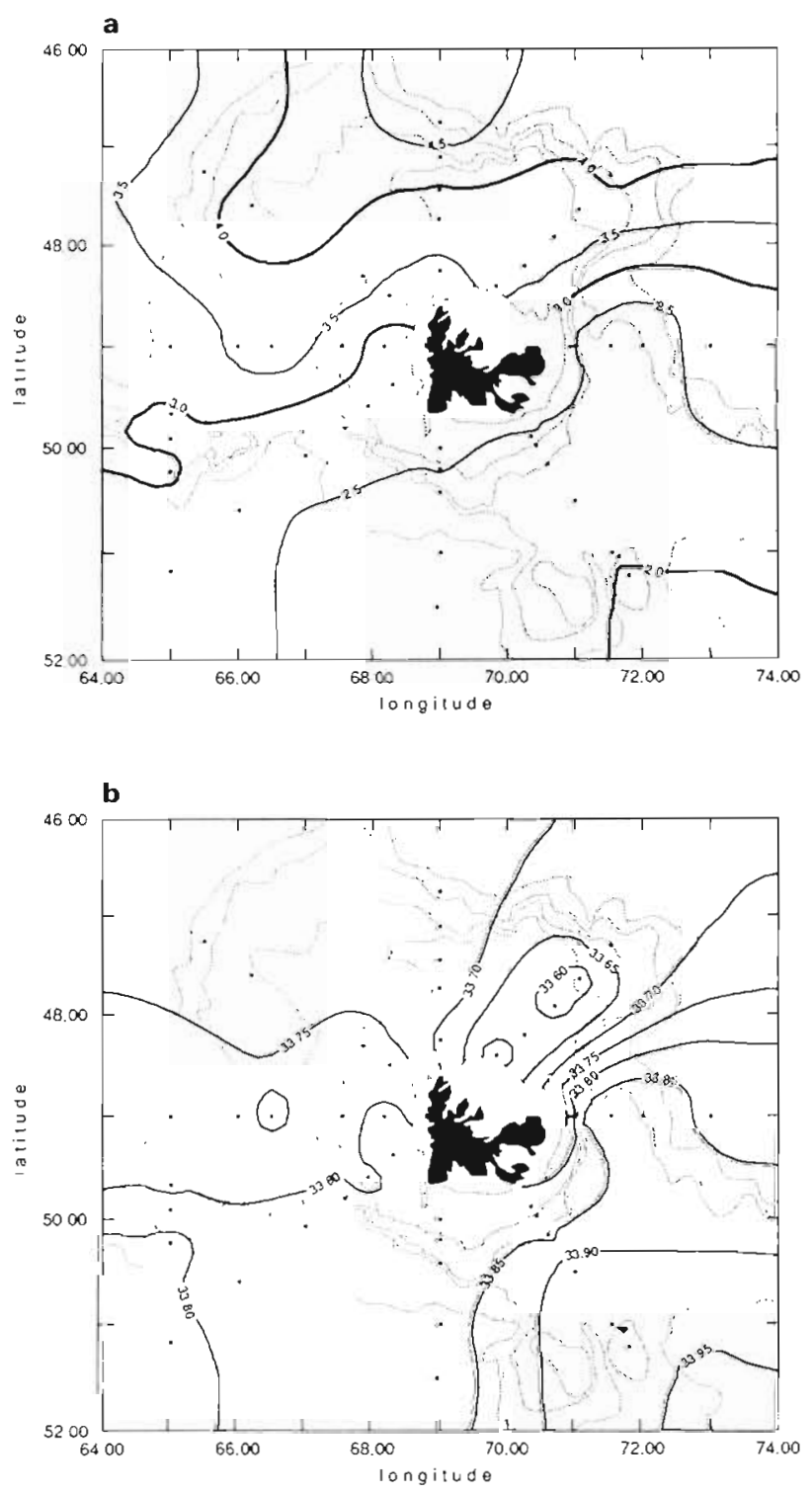

Fig. 5. Hydrologic conditions, winter 1987. (a) Surface temperatures $\left({ }^{\circ} \mathrm{C}\right)$, (b) surface salinities $(\%)$

whose larvae are found in winter (Lepidonotothen mizops), as well as 2 species whose eggs were collected in the plankton only during winter (Notothenia rossii and Champsocephalus gunnari). These results agree with previous information on spawning of these species (Duhamel 1982, 1987a, b). The presence of eggs in the water column suggests that embryonic development may be pelagic for some species of Notothenioidei. This result, first proposed by Camus \& Duhamel (1985) for $N$. rossii, is at variance with the benthic embryonic development hypothesis concerning the Notothenioidei (Marshall 1953). (3) Species whose larvae are found year-round (Krefftichthys anderssoni and Protomyctophum sp.). (4) Rare species, including meso- and bathypelagic fishes (Electrona sp.
Notolepis coatsi and Macrourus sp.) and demersal fishes (Muraenolepis sp.).

Fish larvae showed low overall abundance (Tables 2 \& 3). Krefftichthys anderssoni was the dominant ichthyoplankton in 3 of the 4 seasonal samplings, showing the highest average abundance in all but the summer 1987 series. Myctophids showed the highest average abundances of all recorded taxa (Gymnoscopelus braueri for the summers and autumn, and $K$. anderssoni for winter). The high percentage of stations with abundance equal to 0 indicates a spatial distribution linked not to chance but strongly to the influence of external factors or intrinsic factors of each species, such as spawning period and area.

\section{Multivariate analysis of larval abundance, environmental factors and stations}

\section{Summer 1987}

The 3 groups ( $A, B$ and C) resulting from multivariate analysis (Table 4) each corresponded to a geographically distinct region, characterized by its particular hydrology and topography (Fig. 6).

Group A was clearly distinct from the 2 others. It precisely corresponded to the Kerguelen-Heard seamounts. This region differed from the others by its low temperatures $\left(<4^{\circ} \mathrm{C}\right)$ and high salinities and densities ( $>33.90 \%$ and $>27$ respectively). The 2 other groups ( $\mathrm{B}$ and $\mathrm{C}$ ) could be distinguished from one another on the basis of 3 factors. Two factors were linked to hydrology: first, the $5^{\circ} \mathrm{C}$ isotherm, which is the surface manifestation of the Antarctic Polar Front (Ostapoff 1962), and second, the $33.80 \%$ isohaline. Differences were also observed between the shelf and seamounts and the oceanic zone. Wind factors did not seem to be involved in the observed spatial structure.

Following the classification system, species densities were divided into the last 2 groups. Group B included larvae of deep-living mesopelagic species (Protomyctophum sp. and high densities of Krefftichthys anderssoni). The geographic zone (Zones 2 to 4) associated with this group was bounded on the south by the Kerguelen-Heard seamounts and on the north by the Antarctic Polar Front. The deep northern stations were also included despite hydrological differences. This can be explained by the presence of $K$. anderssoni larvae and by the fact that this group included the deepest stations. Group C included the demersal species (Lepidonotothen squamifrons and Zanchlorhynchus spinifer), the shelf-living mesopelagic species (Gymnoscopelus spp.) and those species the bathymetric distribution of which is limited at a depth of $200 \mathrm{~m}$ (weak densities of $K$. anderssoni). From a topographical 


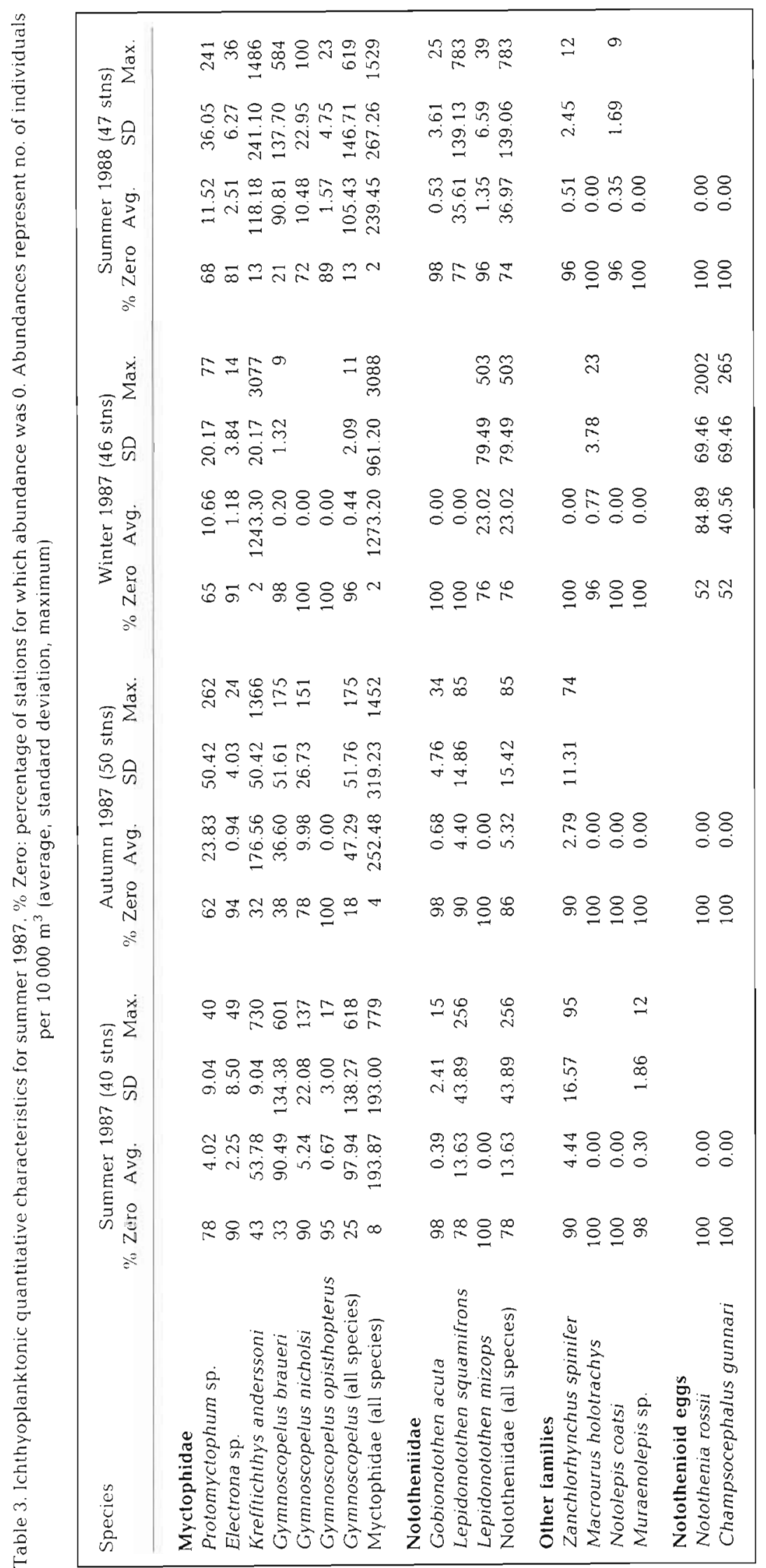




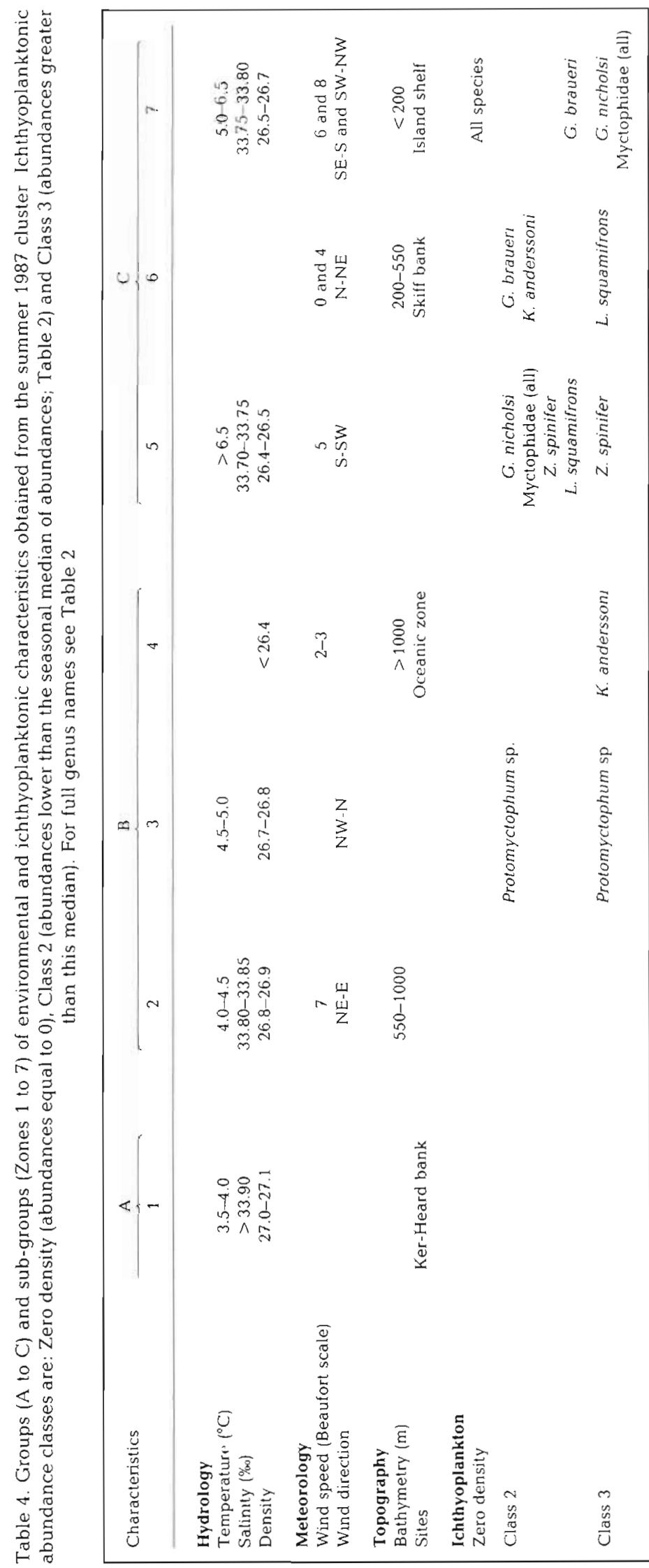




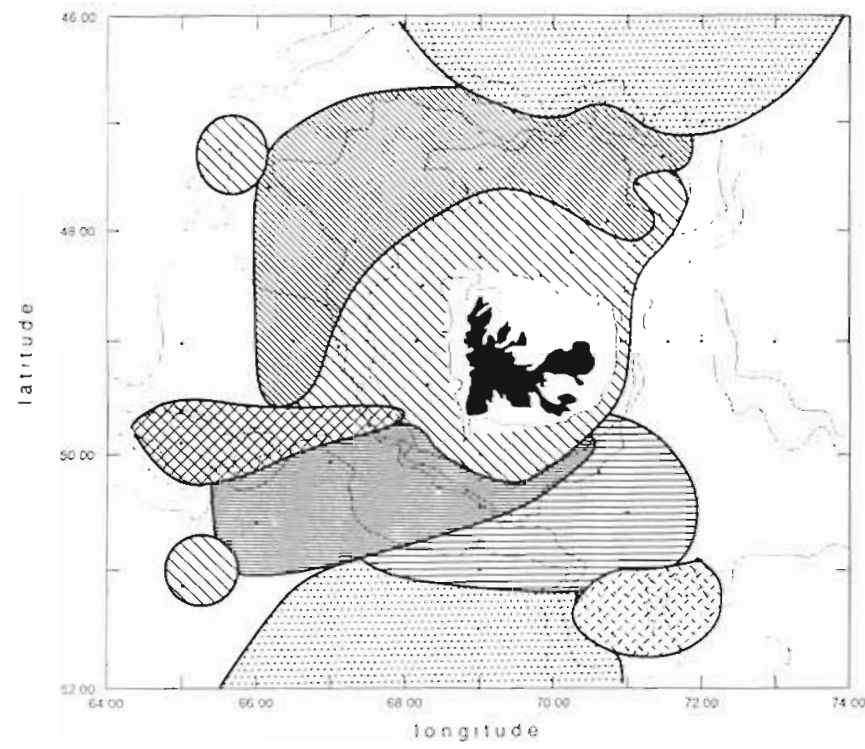

perspective, this group included almost the whole island shelf, as well as the Skiff seamount. In a hydrological context, the characteristics corresponded to the Antarctic Polar Front north zone.

Autumn 1987

Characteristics of the 5 groups resulting from multivariate analysis are given in Table 5. Each of them defined a geographical zone (Fig. 7) with precise hydrologic and topographic characteristics. Wind factors did not affect spatial structure.

Groups D and E were separated from the other groups. Zone 8, linked to Group E, corresponded to Kerguelen-Heard seamounts, with the same hydrologic characteristics as those in summer. Group D geographically corresponded to the channel situated between the island shelf and the Kerguelen-Heard seamounts. Temperatures were between 4 and $4.5^{\circ} \mathrm{C}$. For the other groups, bathymetry and the position of the Antarctic Polar Front (surface temperature ca $5^{\circ} \mathrm{C}$ ), seemed to be the distinctive criteria. Group $\mathrm{A}$, associated with deep oceanic zones, included 2 zones: Zone 1 was limited to the north by the Antarctic Polar Front; Zone 2 corresponded to the deep oceanic zone to the north of the shelf, where densities were $<26.4$. Another group, B, included the shelf's slopes and Skiff seamount. Its physical characteristics were similar to those of the region surrounding the Antarctic Polar Front. Finally, Group $C$ included the shelf. Zones 5 and 6 (linked to this group) were limited to the south by the Antarctic Polar Front and to the north by great depth.

Few differences can be seen for ichthyoplankton when compared with summer results. Myctophids were absent
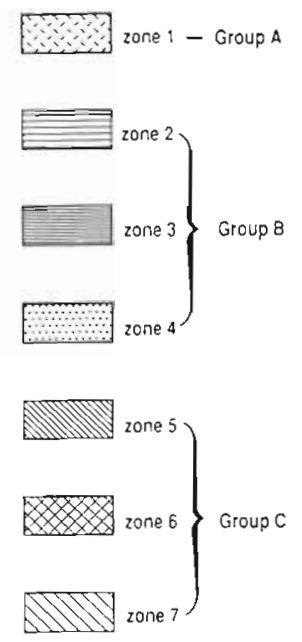

Fig. 6. Summer 1987 Cartogram of zones (sub-group observations; see Table 4) linked to the analysis on the Kerguelen-Heard seamounts (Group E). Protomyctophum sp. larvae were located in autumn to the north of the Antarctic Polar Front, and occurred exclusively outside of the shelf (Zones 2 and 4). Krefftichthys anderssoni larvae concentrated on the slopes (Zone 4), but some of them could be observed on the shelf (Zone 6). Gymnoscopelus spp. larvae favoured the seamounts and some parts of the island shelf (Groups B and C). Only larvae of $G$. braueri were found outside the shelf (Group A). Demersal species (Lepidonotothen squamifrons and Zanchlorhynchus spinifer) were concentrated on the shelf (Group C), even though some Z spinifer specimens were fished above deep zones (Group A). High densities of $L$. squamifrons were observed on the Skiff seamount (Group B). Hydrologic factors separated these 2 species: $Z$. spinifer were found in the warmer waters north of the Antarctic Polar Front, and L. squamifrons in waters surrounding the Antarctic Polar Front.

\section{Winter 1987}

Four groups were identified (Table 6). A cartogram of the observation subgroups is shown in Fig. 8

As in the other seasons, the Kerguelen-Heard seamount region was separated from the other zones (Group C) because of its high salinities ( $>33.90 \%$ ) and densities $(>27.1)$. Another zone (linked to Group D) was characterized by its very low salinities and densities $(<33.65 \%$ and $<26.7$ respectively). The Group A region was limited to the southeast by the Kerguelen-Heard seamounts and to the north by the $3^{\circ} \mathrm{C}$ isotherm. This isotherm is the surface manifestation of the Antarctic Polar Front (Ostapoff 1962), as are the $33.80 \%$ isohaline and 26.9 isopycnal. The deep 


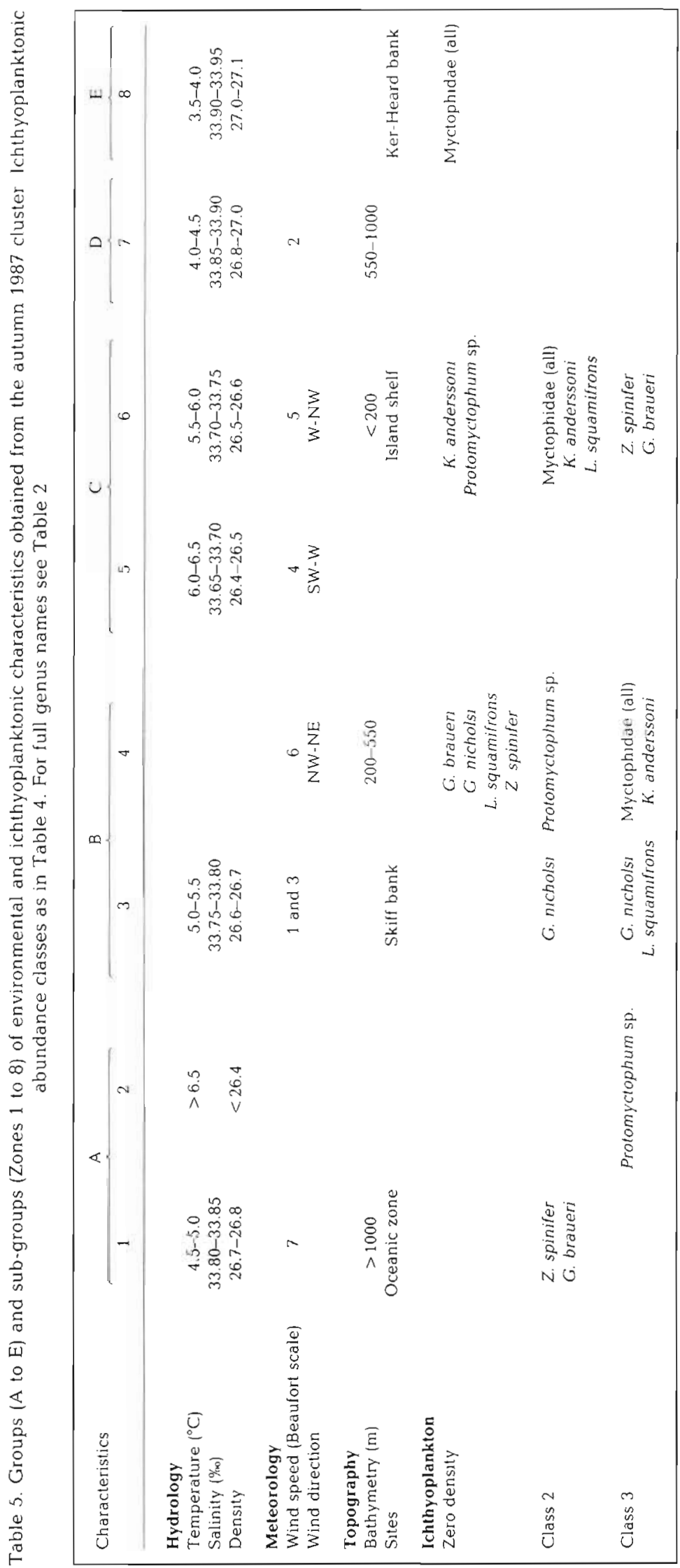



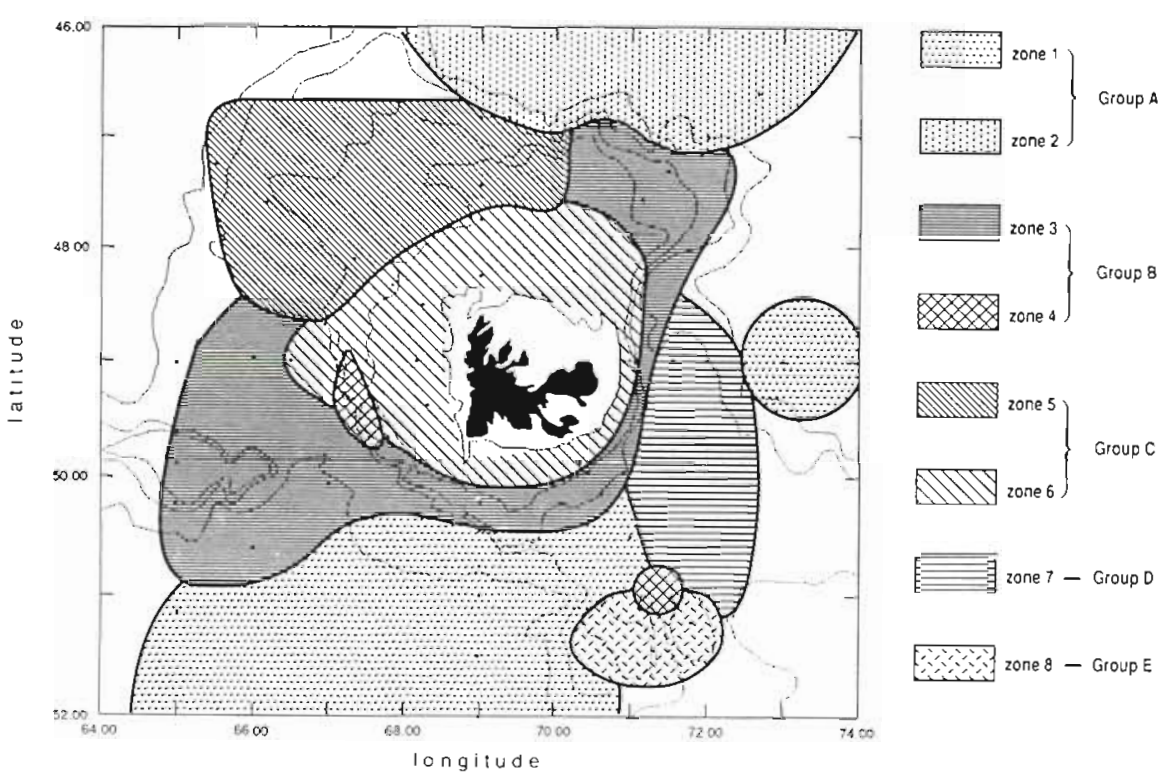

無得 zone 8 - Group E
Fig. 7. Autumn 1987. Cartogram of zones (sub-group observations; see Table 5) linked to the analysis oceanic zone located to the north of the island shelf was also included in this region, since Group B included deep oceanic stations. The area linked to Group B observations corresponded to the north of the Antarctic Polar Front (temperatures $>3^{\circ} \mathrm{C}$ ) and was limited to the north by the great depths. This zone mainly covered half the northern part of the island shelf.

With respect to species, there was a noticeable lack of Myctophidae in the 'less-saline' zone (Group D), which was located north-east of the archipelago. Myctophid species (Krefftichthys anderssoni and Protomyctophum sp.) were found above different depths. $K$. anderssoni larvae, very abundant in winter, were scattered all over the area and were mostly found in the south of the Antarctic Polar Front (Group A). Protomyctophum sp. occurred to the north of this front (Group B). The only demersal species for which larvae were found is Lepidonotothen mizops, the highest densities of which were observed on the Kerguelen-Heard seamounts (Group C). Otherwise, this species mostly occurred in the north of the Antarctic Polar Front (Group B). Finally. all the collected pelagic eggs were from demersal species. Indeed, high densities were observed on the island shelf (Group B), whereas low densities were seen outside of it (Zone 1). This suggests that high winds which very often occur there - and currents carry those eggs above the deep oceanic zone. They may also allow colonization of the shelf by mesopelagic larvae.

\section{Summer 1988}

Four groups were identified (Table 7). A cartogram of the sub-groups is shown in Fig. 9.
The first zone (Group A) covered the KerguelenHeard seamounts. Its thermal and salinity characteristics were identical to those of summer 1987, but its densities were little lower. The second zone (Group B) corresponded to the deep part situated to the north of the shelf. It was hydrologically defined by densities $<26.4$ and by high temperatures $\left(>7^{\circ} \mathrm{C}\right)$. The third zone (Group C) included the island shelf and its slope. It was limited to the south by the $5.5^{\circ} \mathrm{C}$ isotherm and the 26.6 isopycnal, and was therefore to the north of the Antarctic Polar Front. The last group (D) covered Zones 4 to 6 . It was limited to the southeast by the Kerguelen-Heard seamounts and to the north by the Antarctic Polar Front (temperatures $<5.5^{\circ} \mathrm{C}$ ), the $33.75 \%$ isohaline and the 26.6 isopycnal.

As for species, Protomyctophum sp. larvae only occurred above deep oceanic zones (Zone 6). Krefftichthys anderssoni and Gymnoscopelus braueri larvae occurred from the break-point (Group C) to the deep oceanic zone (Zone 6). Yet the highest ichthyoplankton densities were found in the south. Gymnoscopelus nicholsi larvae occurred strictly on the shelf (Zones 3 and 5), especially on its northern part, near the Antarctic Polar Front. Lepidonotothen squamifrons larvae (demersal species) occurred on both the shelf and the Skiff seamount (Group D). They were found mainly near the Antarctic Polar Front (temperatures between 5 and $5.5^{\circ} \mathrm{C}$ ). Zanchlorhynchus spinifer juveniles were strictly dermersal to the north of the Antarctic Polar Front (Zones 3 and 5). Few significant data are available for Lepidonotothen mizops larvae. These are most likely found in the northern part of the archipelago close to the coast. 


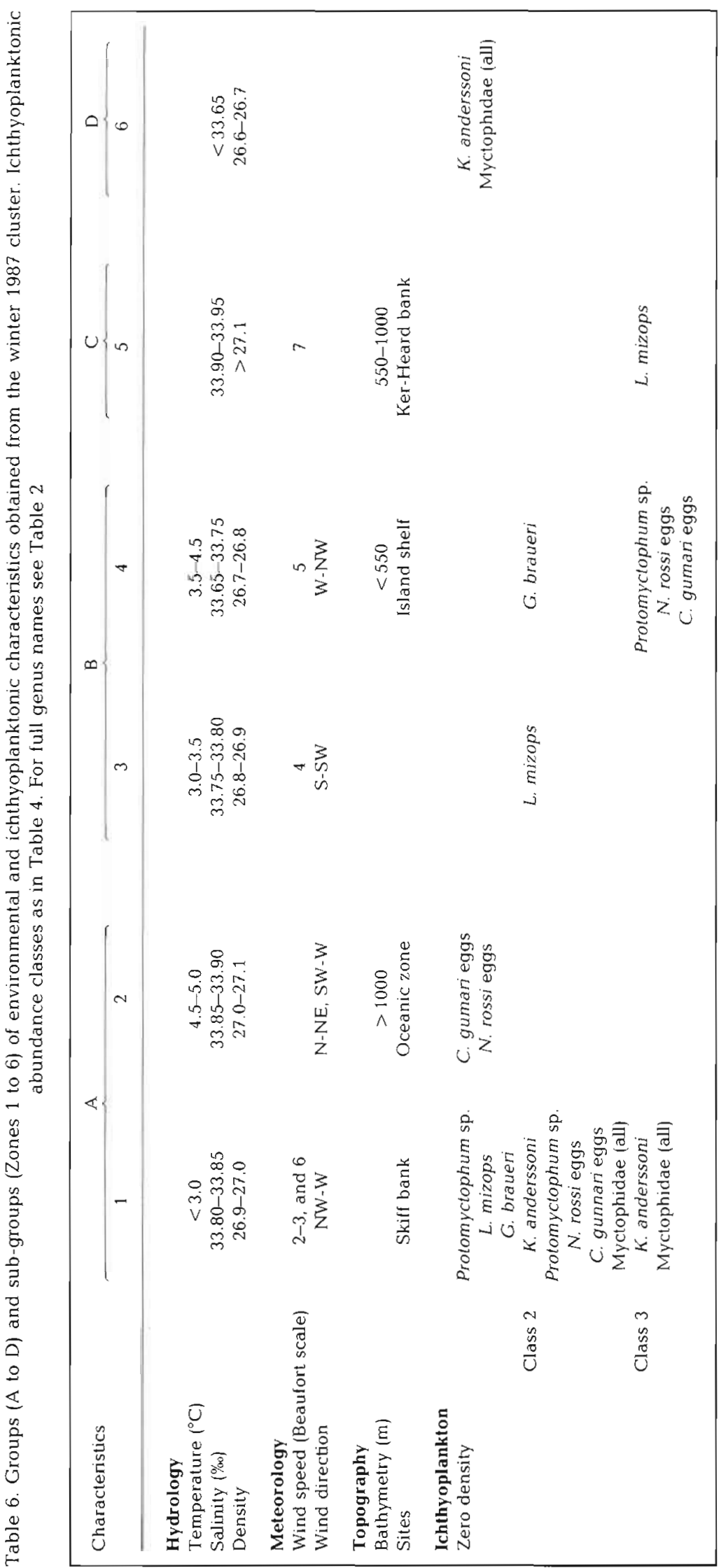



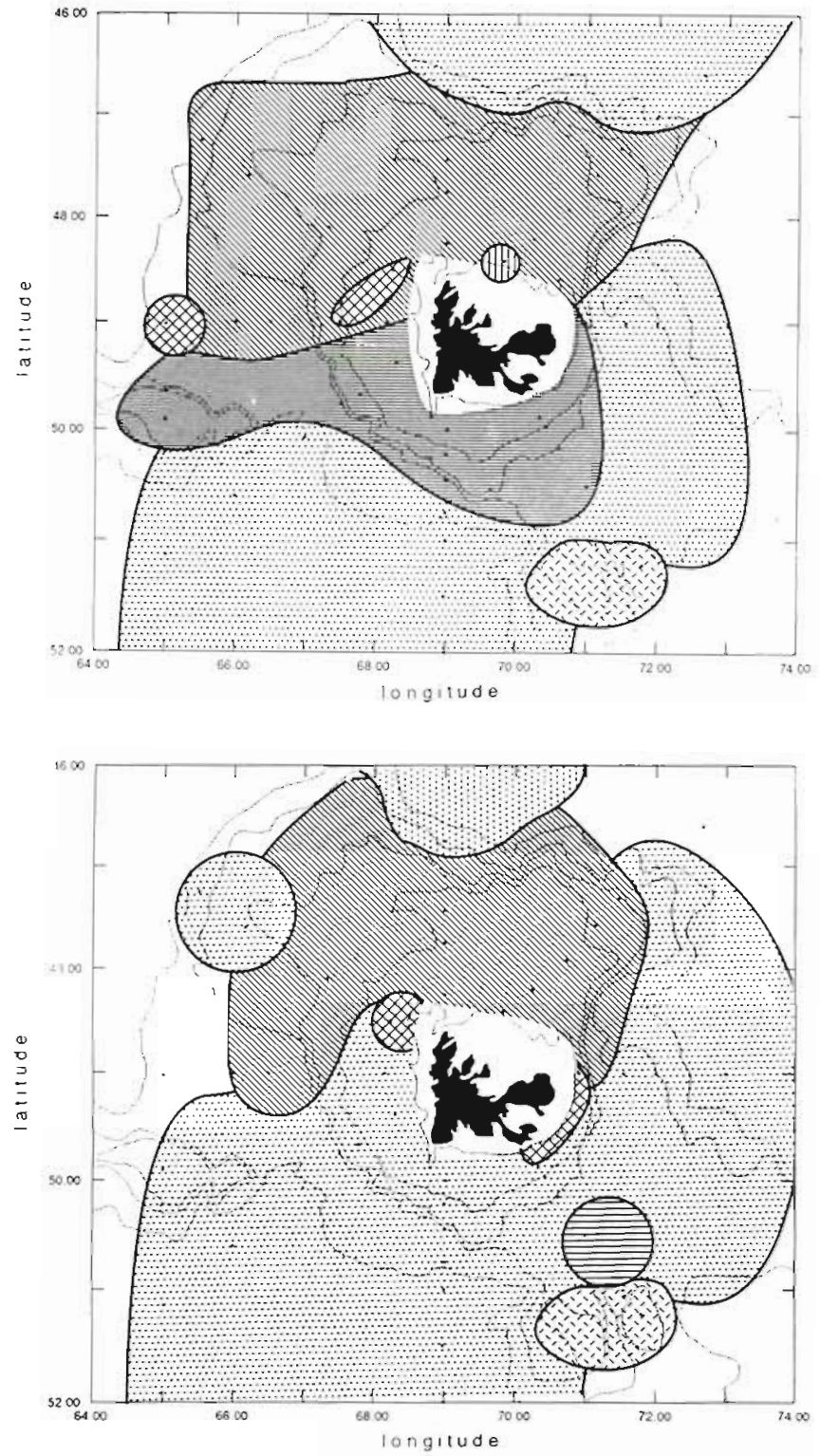

CONCLUSION

By any criterion, differences between summer seasons (autumn included) were minor. On the other hand, their distributions and abundances differed from those of winter.

The study area could be divided into 3 main regions. The first - mainly because of its hydrology - was the Kerguelen-Heard seamount zone (lowest temperatures and highest salinities and densities for the area). The presence of the Antarctic Polar Front and the distinction between the shelf and the deep oceanic zone distinguished the last 2 regions: one was limited to the north by the Antarctic Polar Front and to the southeast by the Kerguelen-Heard seamounts, and included most of the deepest stations, even those

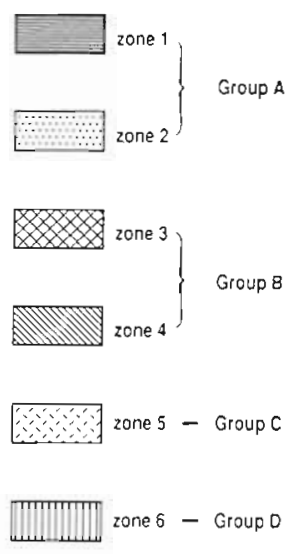

Fig. 8. Winter 1987 Cartogram of zones (sub-group observations; see Table 6) linked to the analysis

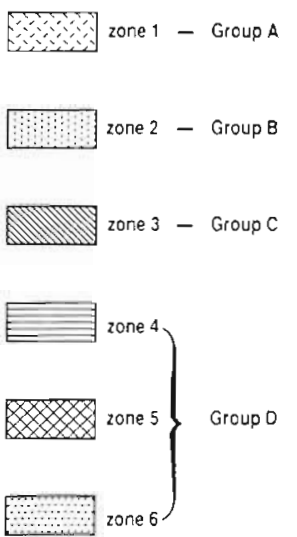

Fig. 9. Summer 1988. Cartogram of zones (sub-group observations; see Table 7) linked to the analysis

located at the north of the studied area; the other covered most of the island shelf, as well as the Skiff seamount. Some variability existed which isolated individual regions. For example, the northeast of the archipelago was distinct in winter, due to the presence there of low-salinity waters. The latitudinal boundary of the Antarctic Front was further north in summer 1988 than in 1987 . Thus, the area south of this front was much wider in 1988.

The spatial distribution of fish larvae was greatly influenced by topographic factors and by hydrology. Wind factors influenced only fish eggs and larvae transport. Two kinds of larvae can be distinguished:

(1) Larvae which occur on the shelf and the surrounding seamounts, such as Lepidonotothen squamifrons, Lepidonotothen mizops and Zanchlorhynchus spinifer. 


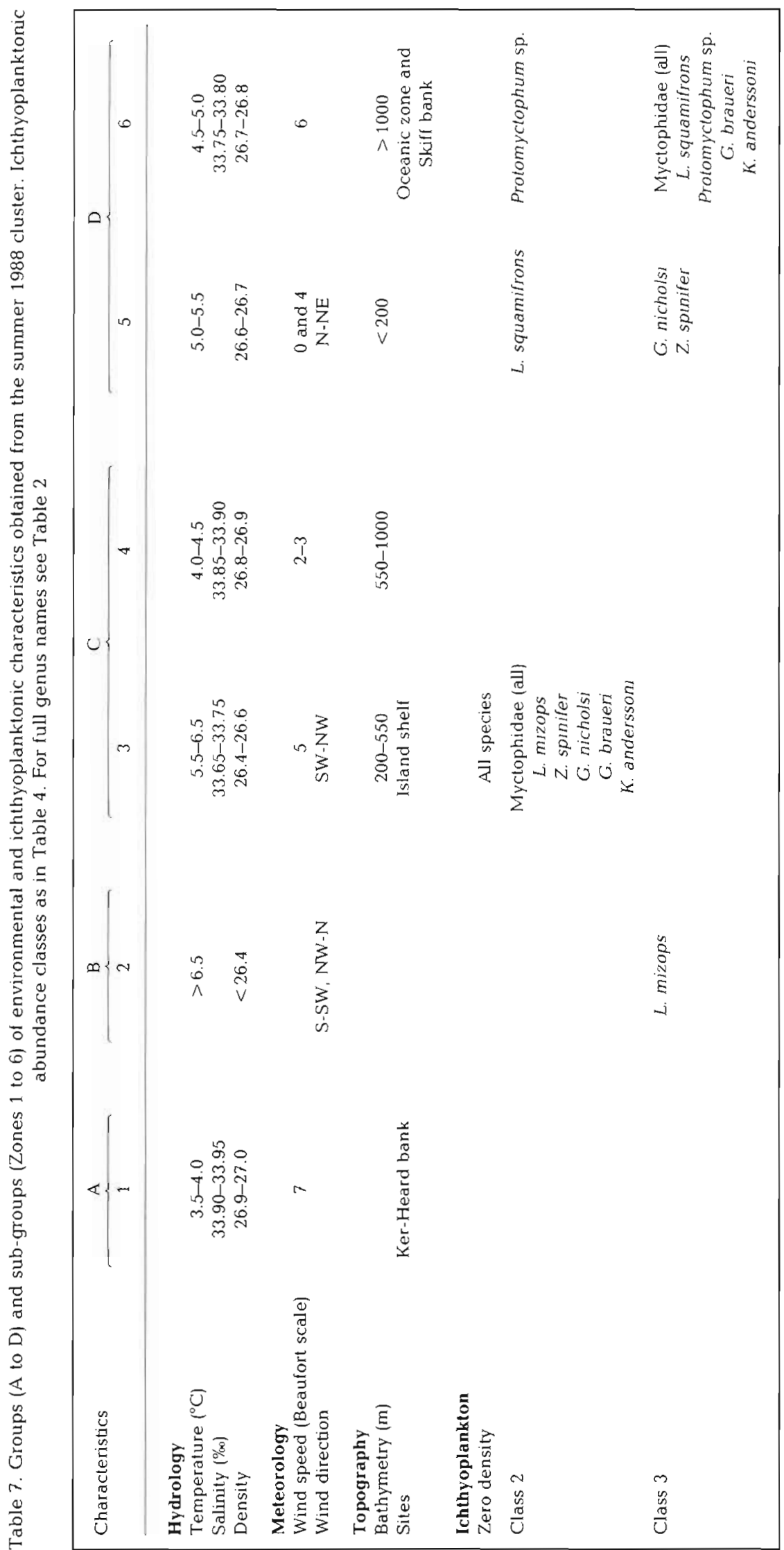


Gymnoscopelus nicholsi, a species defined as bathypelagic (Linkowski 1985), must also be included in this group. These species preferentially occur to the north of the Antarctic Polar Front. The eggs of Notothenia rossii and Champsocephalus gunnari can also be included in this group.

(2) Larvae which occur in the oceanic zone. They all belong to the Myctophidae. Some of them can be found on the slope and to a lesser extent on the shelf, such as Gymnoscopelus braueri and Krefftichthys anderssoni larvae. Hulley (1981) found hydrologic affinities in the adults similar to those that we found for the Kerguelen Islands larvae. According to season, Protomyctophum $\mathrm{sp}$, larvae are located either to the north or to the south of the Antarctic Polar Front. $K$. anderssoni and $G$. braueri occur in the Superficial Antarctic Water and the Antarctic Intermediate Water (Hulley 1981). As these 2 water masses are present in the studied area, the larvae are mainly influenced by topography.

Acknowledgements. We thank the 'Mission de Recherche des Terres Australes et Antractiques Françaises' for their support during the 'Joint French-Soviet Scientific Cruises' aboard the 'Skif' Our gratitude goes to the Soviet scientists and crews and to our French collegues, especially J. M. Lepetitcorps and $N$. de Mahuet. Sampling, calculation, and mapping and interpretation of hydrologic features were realised by $\mathrm{E}$. Charriaud from the 'Laboratoire d'Océanographie Physique' of the Muséum National d'Histoire Naturelle in Paris. Numerical analyses were performed at the 'CEROV' thanks to the kind collaboration of $\mathrm{M}$. Etienne for computer operation. We owe the English version of the manuscript to $C$. Barillon. We thank him for his friendly and priceless collaboration.

\section{LITERATURE CITED}

Azibane, C., Clavier, B., Dujardin, J. L., Le Touze, V., Rigourd, J. F. (1977). Etude sur le climat des iles Kerguelen et de la zone subantarctique de l'océan Indien. Climatologie de Port-aux-Français. Monogr. Météorol. Natl. 99: 1-130

Bekker, V E. (1985). Distribution of myctophid fishes and the position of the biogeographical border between the islands of Saint Paul and Kerguelen. J. Ichthyol. 25 (2): 159-162

Camus, P., Duhamel, G. (1985). Ponte et développement embryonnaire de Notothenia rossii rossii (Richardson, 1844), Nototheniidae des îles Kerguelen. Cybium 9 (3): 283-293

Charriaud, E., Gambéroni, L. (1987). Observations hydrologiques et flux géostrophique entre les îles Kerguelen et Amsterdam - Résultats de la Campagne KERAMS1 (16-20 février 1987). Rapp. Interne Lab. Oceanogr Phys./ Museum Nat. Hist. Nat., Paris

Deacon, G.E.R. (1934). Die Nordgrenzen antarktischen und subantarktischen Wassers im Weltmeer Annalen Hydr Mar. Meteorol. 42: 129-134

Duhamel, G. (1982). Biology and population dynamics of

This article was submitted to the editor
Notothenia rossii rossii from the Kerguelen Islands (Indian sector of Southern Ocean). Polar Biol. 1: 141-151

Duhamel, G. (1987a). Ichtyofaune des secteurs indien occidental et atlantique oriental de l'océan Austral: biogéographie, cycles biologiques et dynamique des populations. Thèse de Doctorat d'Etat ès Sciences Naturelles, Université Paris VI

Duhamel, G. (1987b). Reproduction des Nototheniidae et Channichthyidae des îles Kerguelen. In: Colloque sur l'écologie marine des îles subantarctiques et antarctiques (Paris 25 juin 1985). CNFRA 57: 91-107

Duhamel, G., Ozouf-Costaz, C. (1985). Age, growth and reproductive biology of Notothenia squamifrons Günther, 1880 from the Indian Sector of the Southern Ocean. Polar Biol. 4: 143-153

Efremenko, V N. (1979). Atlas of fish larvae of the Southern Ocean. Cybium 7 (2): 1-74

Fischer, W. Hureau, J. C. (1987). Fiches FAO d'identification des espèces pour les besoins de la pêche. Océan Austral (Zones de pêche 48,58 et 88 ) (Zones de la Convention CCAMLR\}. Vols. $1 \& 2$, FAO, Rome

Gambéroni, L., Geronimi, P., Jeannin, P. F., Murail, J. F (1982). Study of frontal zones in the Crozet-Kerguelen region. Oceanol. Acta 5 (3): 289-299

Hulley, P. A. (1981). Results of the research cruises of FRV Walther Herwig to South America. LVIII Family Myctophidae (Osteichthyes, Myctophiformes). Arch. Fisch.Wiss. $31(1): 1-300$

Hureau, J. C. (1982). Methods for studying early life history stages of Antarctic fishes. Cybium 6 (1): 43-51

Kellermann, A. (1986). Zur Biologie des Jugendstadien der Notothenioidei (Pisces) an der Antarktischen Halbinsel. Ber. Polarforsch. (Bremerhaven) 31: 1-155

Kellermann, A. (1989). Catalogue of early life stages of Antarctic Notothenioid fishes. In: Identification key and catalogue of larval Antarctic fishes. Biomass scient. Ser. 10: 1-136

Koubbi, P., Duhamel, G., Camus, P. (1990). Early life stages of Notothenioidei (Pisces) from the Kerguelen Islands. Cybium 14 (3): 225-250

Lance, G. N. Williams, W T (1967). A general theory of classificatory sorting strategies. I. Hierarchical systems. Comput. J. 9: 373-380

Ledenev, V. G. (1966). Antarctic convergence in the western part of the Indian sector of the Southern Ocean. Sov. Ant. Exp. Inf. Bull. 57/58: 112-116

Linkowski, T B. (1985). Population biology of the myctophid fish Gymnoscopelus nicholsi (Gillberg, 1911) from the western-south Atlantic. J. Fish. Biol. 27: 683-698

Marshall, N. B. (1953). Egg size in arctic, antarctic and deepsea fishes. Evolution 7: 328-341

Moser, H. G., AhIstrom, E. H. (1970). Development of lanternfishes (family Myctophidae) in the California current. Part 1: Species with narrow-eyed larvae. Bull. Los Angeles Cty Mus. Sci. 7. 1-145

North, A. W., White, M. G. (1982). Key to fish postlarvae from the Scotia sea, Antarctica. Cybium 6 (1): 13-32

Ostapoff, F. (1962). The salinity distribution at 200 metres and the Antarctic frontal zones. Dt. hydrogr. Z. 15: 133-141

Smith, P. E., Richardson, S. (1977). Standard techniques for pelagic fish egg and larval surveys. FAO Fish. Tech. Pap. 175: $1-100$

Volle, M. (1985). Analyse des données. Economica, Paris

Manuscript first received: July 30, 1990

Revised version accepted: March 11, 1991 